\title{
Global Journal of Environmental Science and Management
} (GJESM)

Homepage: https://www.gjesm.net/

\section{REVIEW PAPER}

\section{Increasing resident participation in waste management through intrinsic factors cultivation}

\author{
Sunarti $^{1, *}$ J.H. Tjakraatmadja ${ }^{1}$, A. Ghazali ${ }^{1}$, B. Rahardyan ${ }^{2}$ \\ ${ }^{1}$ School of Business and Management, Institut Teknologi Bandung, Indonesia \\ ${ }^{2}$ Faculty of Civil and Environmental Engineering, Institut Teknologi Bandung, Indonesia
}

\begin{tabular}{l} 
ARTICLE INFO \\
Article History: \\
Received 25 August 2020 \\
Reviewed 22 October 2020 \\
Revised 12 November 2020 \\
Accepted 26 November 2020 \\
\hline
\end{tabular}

\section{Keywords:}

Developing Countries Determinant Factors Resident Participation Waste Management Behaviour Waste Problems

\begin{abstract}
BACKGROUND AND OBJECTIVES: Resident participation in waste management is essential to overcome waste problems effectively. In many developing countries, the local government has been struggling to encourage resident involvement in the waste management process, but the participation rate is still low. Thus, it requires a system that can encourage residents to participate effectively and sustainably. Therefore, this study aimed to determine what determinant factors, either extrinsic or intrinsic, significantly improve resident participation by changing behaviour toward waste management. METHODS: This study tried to get insights from previous studies about key determinant factors affecting resident behaviour toward waste management to improve participation, significantly using a literature review method.

FINDINGS: Educational setting for residents is crucial to improve waste management participation by cultivating key intrinsic factors with support from extrinsic factors that lead to changing behaviour. This study identified eight types of key contents shared in the educational setting to ensure its improvement. Key intrinsic factors should be cultivated, including six kinds of knowledge and five emotional domain factors. The six critical types of knowledge include technical experience, waste management performance knowledge, perception of benefits, environmental awareness, understanding of individual and social responsibility, and understanding the social norms and regulations. The five intrinsic factors in the emotional domain include environmental efficacy, motivation, personal moral norms, PBC, and Attitude toward waste management. All the critical determinant factors, including intrinsic and extrinsic factors, should support each other to improve residents' behaviour, leading to sustainable participation.

CONCLUSION: Relevance of educational content to the residents is crucial to ensure educational intervention effectiveness. With full support from the antecedent factors, waste management behaviour can be nurtured sustainably, significantly increasing the participation rate. Combining extrinsic and intrinsic factors is recommended to ensure the effectiveness of the improvement of resident participation.
\end{abstract}

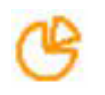

NUMBER OF FIGURES

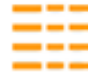

NUMBER OF TABLES
NUMBER OF REFERENCES 113

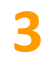

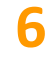

*Corresponding Author:

Email: sunarti@sbm-itb.ac.id

Phone: +62 81325115551

Fax: +62222510102

Note: Discussion period for this manuscript open until April 1, 2021 on GJESM website at the "Show Article. 


\section{INTRODUCTION}

The accumulation of municipal waste generation is one of the main problems in every country throughout the world. Its number keeps increasing parallel with population growth, urbanization, industrialization, and economic growth (Borongan and Okumura, 2010). The waste generation will increase up to $70 \%$ from 2016 to 2050 due to massive population growth and urbanization (World Bank, 2018). Household waste commonly dominates compositional characteristics of Municipal Solid Waste (MSW) (Aleluia and Ferrão, 2016), presented by a high percentage of vegetable and food waste in the MSW composition. Table 1 shows some examples of compositional characteristics of MSW in several developing countries.

Due to their contribution to the domination of MSW, residents become one of the critical stakeholders in the waste management process (Kamaruddin et al., 2017; Owamah et al., 2017). Residents play various roles in the waste management process, including waste reduction (Abbasi, 2018), waste separation at source (Areeprasert et al., 2018; Heidari et al., 2018; Boonrod et al., 2019; Priti and Mandal, 2019), and waste recycling (Kamaruddin et al., 2017; Ma et al., 2018). Moreover, $3 \mathrm{R}$ (Reuse, Reduce, Recycle) is the most preferred solution for diverse countries due to its effectiveness in controlling waste generation (Borongan and Okumura, 2010; Modak et al., 2016). Therefore, encouraging resident participation is vital (Mukama et al., 2016; Song et al., 2016; Sekito et al., 2018) for sustainable waste management (Kawai et al., 2016; Ma et al., 2018; Boonrod et al., 2019). Resident participation can succeed in the waste management system in many countries (Zahra et al., 2012; Nmere et al., 2020). Even though it is vital to involve residents in waste management process from the source, resident participation in developing countries is mostly lacking, far behind developed countries. Banerjee and Sarkhel (2019) found that $60 \%$ of cities from developed countries practice more complicated separation at source, while $87 \%$ of cities in developing countries mix their waste and rely on authorities to handle it, implying gaps in various aspects of the waste management system (Marshall and Farahbakhsh, 2013). Furthermore, only about $20 \%$ of cities in the developing countries can process the waste further, showing a lack of knowledge and skill on waste management (Borongan and Okumura, 2010; Banerjee and Sarkhel, 2019). Thus, developing countries are still struggling in improving waste participation, especially in separation at the source step. Local governments in developing countries should find effective ways to encourage resident participation, not only on the waste separation but also in waste reduction and recycling (Kawai et al., 2016). To find the strategies, it is not merely by adopting the system implemented in developed countries due to its difference in the context. Instead, there should be some consideration toward various factors, including residents' characteristics, economic, cultural, and so forth (Kawai et al., 2016). Some studies showed that most developing countries relied on extrinsic strategies as the determinant factors to encourage participation and improve their behaviour toward waste management. For instance, the extrinsic approaches are policy enforcement (Heidari et al., 2018; Ma et al., 2018; Putri et al., 2018), incentives

Table 1: MSW compositional characteristics from various cities in developing countries

\begin{tabular}{|c|c|c|c|c|c|}
\hline Composition & $\begin{array}{l}\text { Esmaeilizadeh et } \\
\text { al. (2020) } \\
\text { (Iran) }\end{array}$ & $\begin{array}{c}\text { Speier et al. (2018) } \\
\text { (Bangalore City, } \\
\text { India) }\end{array}$ & $\begin{array}{l}\text { Sekito et al. (2018) } \\
\text { (Malang City, } \\
\text { Indonesia) }\end{array}$ & $\begin{array}{l}\text { Xu et al. (2016) } \\
\text { (Xiamen, China) }\end{array}$ & $\begin{array}{l}\text { Laohalidanond et al. } \\
\qquad(2015) \\
\text { (Bangkok, Thailand) }\end{array}$ \\
\hline $\begin{array}{l}\text { Vegetable and food } \\
\text { waste }\end{array}$ & $68,40 \%$ & $56,43 \%$ & $41,00 \%$ & $66,19 \%$ & $49,90 \%$ \\
\hline Paper/cardboard & $7,31 \%$ & $7,67 \%$ & $8,50 \%$ & $9,89 \%$ & $8,50 \%$ \\
\hline Plastics & $9,80 \%$ & $8,50 \%$ & $26,00 \%$ & $13,17 \%$ & $28,50 \%$ \\
\hline PET (plastic bottle) & $0,99 \%$ & - & - & - & - \\
\hline Metal & $1,59 \%$ & $0,23 \%$ & $3,60 \%$ & $1,06 \%$ & $1,40 \%$ \\
\hline Rubber & $1,09 \%$ & - & - & - & - \\
\hline Textile & $3,02 \%$ & $4 \%$ & $6 \%$ & $4,38 \%$ & $5,20 \%$ \\
\hline Glass & $2,33 \%$ & $1,27 \%$ & - & $3,61 \%$ & $4,40 \%$ \\
\hline Wood/leaves & $0,97 \%$ & $0,33 \%$ & $9,20 \%$ & $0,6 \%$ & - \\
\hline Others & $4,48 \%$ & $21,47 \%$ & $6,00 \%$ & $1,10 \%$ & $2,10 \%$ \\
\hline
\end{tabular}




\section{For More Pages, Please Go To https://dx.doi.org/10.22034/gjesm.2021.02.10}


For More Pages, Please Go To
https://dx.doi.org/10.22034/gjesm.2021.02.10 


\section{For More Pages, Please Go To https://dx.doi.org/10.22034/gjesm.2021.02.10}




\section{For More Pages, Please Go To https://dx.doi.org/10.22034/gjesm.2021.02.10}




\section{For More Pages, Please Go To https://dx.doi.org/10.22034/gjesm.2021.02.10}




\section{For More Pages, Please Go To https://dx.doi.org/10.22034/gjesm.2021.02.10}




\section{For More Pages, Please Go To https://dx.doi.org/10.22034/gjesm.2021.02.10}


constructs, Ajzen viewed these two constructs are similar because PBC consists of self-efficacy and controllability toward the intended behaviour (Sujata et al., 2019). Among waste management behaviour being studied in the previous studies, PBC was dominantly investigated in studies related to waste separation behaviour. The reasons can be due to the less popularity of the recycling activity in developing countries because they are commonly encouraged to conduct waste separation. In contrast, recycling is handled by the authorities (Marshall and Farahbakhsh, 2013). On the other hand, recycling activity is commonly related to waste separation to valuable inorganic waste being sold, which does not require any treatment in advance. $\mathrm{PBC}$ was proven to be significant in affecting waste separation behaviour of residents in various cities in China (Yuan et al., 2016; Xu et al., 2017, 2018; Wang et al., 2020b), residents in Ghana Millenium City (Alhassan et al., 2020) and also university students in University Teknologi Malaysia (Ayob et al., 2017). The main reason of perception that affected their intention to conduct waste separation is perceived time availability (Song et al., 2016; Choon et al., 2017; Trihadiningrum et al., 2017; Gyimah et al., 2019; Kattoua et al., 2019; Loan et al., 2017; Alhassan et al., 2020; Setiawan, 2020; Ma et al., 2020). Also, the perception toward time cost-burdened the residents in Klang Valley, Malaysia (Choon et al., 2017) and residents in Surabaya City, Indonesia (Trihadiningrum et al., 2017), causing laziness to change their past behaviour. It can be the indication that they perceived waste separation to be not easy to do (Ramadan et al., 2016; Trihadiningrum et al., 2017; Xiao et al., 2017; Heidari et al., 2018; Sekito et al., 2018; Ma et al., 2020). When residents think the waste separation procedure is easy, they tend to do it. Similarly, when they believe it is hard to do the separation, they tend to leave it (Choon et al., 2017). Moreover, Trihadiningrum et al. (2017) contended that a lack of environmental concern might cause laziness toward waste separation. Besides time availability and perceived difficulty, space, as well as facilities availability, also affected residents' PBC, which eventually affect their behaviour toward waste separation as shown by the findings from various studies (Loan et al., 2017; Trihadiningrum et al., 2017; Gyimah et al., 2019; Kattoua et al., 2019; Sujata et al., 2019; Alhassan et al., 2020). However, the study conducted by Xu et al. (2017) and Zhang et al. (2019) showed an insignificant effect of PBC on intention in China. It can be because their behaviour toward waste separation was more influenced by subjective norms and past behaviour, instead of their capability and convenience to do it (Zhang et al., 2019). It implies that regardless of their perception of their incapability in doing waste separation, they may still conduct it because it has been their habit and becomes their social culture. As a result, they may practice improperly. Accordingly, to improve PBC toward waste management behaviour, Choon et al. (2017) suggested that Malaysian authorities make sure that their residents have sufficient knowledge toward simple waste separation methods to lessen residents' reluctance to do the separation. Similarly, when investigating Waste Bank as a communalbased recycling system implemented in Malang City, Indonesia, in 2013, Sekito et al. (2018) suggested more simplicity on the separation process to elevate residents' motivation to participate. Furthermore, Liu et al. (2019) and Xu et al. (2018) suggested external factor completion such as availability of facilities, while Yuan et al. (2016) recommended raising resident's consciousness toward their responsibility toward waste problems to support the formation of PBC. Furthermore, personalised feedback in the form of exposure toward recyclable implementation and monitoring data dissemination is also required (Fan et al., 2019; Xu et al., 2018), to improve their confidence toward their capacity in implementing waste management (Wang et al., 2020b; Xu et al., 2018).

\section{Intention}

The intention factor is discussed mainly in the studies focusing on waste separation behaviour (Janmaimool and Denpaiboon, 2016; Mukama et al., 2016; Song et al., 2016; Xu et al., 2017; Heidari et al., 2018; Liao et al., 2018; Sekito et al., 2018; Ulhasanah and Goto, 2018; Fan et al., 2019; Gyimah et al., 2019; Issock et al., 2020; Wang et al., 2020b), while only two studies are investigating about waste recycling behaviour (Elayan and Ibrawish, 2017; Wang et al., 2020a). Although the study by Sekito et al. (2018) focused on recycling behaviour in Indonesia, they investigated the intention to separate waste, which proved crucial to encourage people to conduct recycling. It is understandable since waste separation is the beginning process before waste is recycled. The 


\section{For More Pages, Please Go To https://dx.doi.org/10.22034/gjesm.2021.02.10}


compared to habits. However, Stern et al. (1999) contended that habits might be disrupted when intervention such as educational activities improve individual dispositions that eventually form new behaviour. In this case, subjective norms can be the best way to develop new habits through social norms along with regulations, as indicated by some studies (Xu et al., 2017; Liao et al., 2018; Salem et al., 2020; ). Subjective norms can be moderated by regulation to affect Intention (Xu et al., 2017). Therefore, Xu et al. (2017) suggested local governments in China adjust local regulation to the social norms to promote waste management behaviour toward households effectively.

\section{Habits}

Habits are defined as a series of learned acts which have been automatic and unconscious, based on specific triggers (Hollingworth and Barker, 2017). The studies about habitual factors of residents in developing countries are only found to be discussed in waste separation behaviour (Oduro-Kwarteng et al., 2016; Ramadan et al., 2016; Xu et al., 2017; Liao et al., 2018; Ulhasanah and Goto, 2018; Fan et al., 2019). In comparison, habitual factors concerning recycling behaviour and reduction behaviour are only found in developed countries such as European Union (Minelgaitè and Liobikienè, 2019), Germany, and Israeli (Mintz et al., 2019). Commonly developing countries are still dealing with separation problems in which residents' participation in waste separation is encouraged while recycling activities are mostly handled by the local authorities (Banerjee and Sarkhel, 2019). The study conducted by Fan et al. (2019), investigating the waste separation behaviour of households in Shanghai, China, in 2014, found that habits had a significant effect on Chinese residents' behaviour. The habits can be presented by repeating past behaviour, which positively influence willingness and separation behaviour (Liao et al., 2018; Fan et al., 2019). The effect of past behaviour is more significant to the residents in Hangzhou, China, compared to subjective norms and PBC (Xu et al., 2017). The substantial effect of habits toward waste separation behaviour is also proven through the study conducted by Ramadan et al. (2016) and Ulhasanah and Goto (2018). They found that residents in Indonesia who were not familiar with waste separation tended to show a low willingness to do the long-term separation. Also, Oduro-Kwarteng et al. (2016) argued that unfamiliarity to waste separation activity, which tends to need full commitment to do, makes this activity often forgettable by Kumasi residents in Ghana, especially if separation activity is not their basic routine activities. Therefore, habits can intervene realization of intention to behaviour resulting Intention-Action Gaps phenomenon (Hollingworth and Barker, 2017). For instance, some people did not practice waste management due to laziness to change or just forgot doing it (Choon et al., 2017; Trihadiningrum et al., 2017). It indicated the role of habits as moderating factors toward intention to action. Xu et al. (2017) and Liao et al. (2018) suggested publication about separation performance in the public place to make public informed toward the existing behaviour. The information about the existing performance would encourage formation of social norms required to stimulate positive habits development toward waste management. In addition, habits can be enhanced by encouraging residents to practice it daily through habituation as an education method. Such a habituation process will create social norms pro to the new habit formation (Salem et al., 2020). The habituation process has been successful in forming new habits of Chinese residents (Xu et al., 2017; Liao et al., 2018). To reduce the effect of negative habits toward waste management behaviour, Fan et al. (2019) encouraged strengthening the intention power to convert it to be behaviour.

\section{Motivation}

Motivation is defined as a driver (internal or external) of behaviour related to waste management. Motivation is found to be discussed in term of waste separation behaviour (Tiew et al., 2015a; 2015b; Heidari et al., 2018; Fan et al., 2019; Limon et al., 2020) and waste recycling behaviour (Heidari et al., 2018; Lawrence et al., 2020). Motivation is found to be a substantial determinant of the waste separation and recycling behaviour of residents in Malaysia (Tiew et al., 2015a; 2015b), China (Fan et al., 2019), Trinidad and Tobago (Lawrence et al., 2020), and university students in Iran (Heidari et al., 2018). The motivation can keep the resident behaviour longerlasting (Tiew et al., 2015a; Lawrence et al., 2020). Intrinsic motivation can be nurtured based on the consideration of environmental conservation (Tiew et al., 2015a; Fan et al., 2019; Lawrence et al., 2020) 
plays a vital role in their culture. Eventually, social norms should be included in the educational content to ensure the residents understand it.

\section{Proposed model}

Based on a thorough analysis of waste management behaviour conducted previously, the proposed model is built based on two primary areas: extrinsic and intrinsic factors. The extrinsic factors refer to any intervention factors outside the personal domain that could affect personal behaviour. In contrast, intrinsic factors are determinant factors inside the personal domain that involves the behaviour realization process (Stern, 1999). In the area of intrinsic factors, there are three primary domains: knowledge, emotional and behavioural level, which are inspired by the behavioural theory concepts indicating the process of how an individual can finally do a certain behaviour (Lickona, 1991; Stern, 1999; Ajzen, 2005). Some interventions can be involved to improve personal behaviour. Previous studies related to waste management behaviour identified that extrinsic factors were significantly affecting the improvement of waste management behaviour, including education, economic factors, supporting facilities, regulations, and social norms. The education is to share facts, values, and information as the education contents (Stern, 1999). Relevant contents being shared in the educational system are vital to ensure the relevance of knowledge received by the households, which are significantly influential in improving certain intrinsic factors (Janmaimool and Denpaiboon, 2016; Hammami et al., 2017; Xu et al., 2017; Yeung and Chung, 2018). It is identified eight primary contents required to be educated to the households, as shown in Table 6. The contents should address the relevant issues to make them effective (Knickmeyer, 2019). The education will improve technical knowledge (including skills on doing the waste management procedure), knowledge about recent waste management performance in the given area, the perceived environmental and economic benefits from waste management, environmental awareness, knowledge about relevant social norms and regulations, and also understanding toward residents' responsibility to waste management. The direct effect of knowledge acquired by the residents improves key intrinsic factors on the emotional level (Hammami et al., 2017; Xu et al., 2017; Wang et al., 2020a), such as residents' trust toward authorities, environmental efficacy, motivation, personal moral norms, and subjective norms. The perceived norms from the community have reciprocal effects on personal moral norms. On the other hand, the combination of personal moral norms and motivation will be powerful to improve attitude toward waste management (Mukama et al., 2016). The motivation should be nurtured through the combination of perception of benefits and environmental awareness (Wadehra and Mishra, 2018) while also influenced by environmental efficacy (Ramadan et al., 2016) and personal moral norms, as a result of understanding toward residents' responsibility toward the environment (Abdelradi, 2018; Tiew et al., 2015a). The environmental efficacy itself should be built from the perception of benefits, environmental awareness, understanding of responsibility, and trust to the authorities, which is the effect of knowledge toward recent waste management performance (Wang and Hao, 2020; Xu et al., 2018). The combination of technical knowledge, support of facilities, and environmental efficacy will improve PBC (Yuan et al., 2016; Xu et al., 2018; Liu et al.., 2019). When PBC is combined with motivation and personal norms, it will affect the attitude toward waste management (Yuan et al., 2016; Yukalang et al., 2017; Liu et al., 2019). The given attitude will eventually cause the intention to do waste management (Addo et al., 2017; Xu et al., 2017; Almasi et al., 2019). The PBC and personal moral norms separately can also cause intention to do waste management, but the intention will be weak if there is no existing positive attitude (Mukama et al., 2016; Heidari et al., 2018; Liu et al., 2019; Issock et al., 2020; Wang et al., 2020a). When it comes to converting intention to behaviour, economic factors, subjective norms, and the existing habits play as moderating factors that may loosen or strengthen the realization (Kattoua et al., 2019; Issock et al., 2020; Wang et al., 2020b). If the intention is weak due to a lack of support from antecedents and extrinsic factors, the existing habits will determine the behaviour realization (Wang et al., 2020b). Therefore, the key contents in the educational system should meet the requirements, and those key contents should be able to nurture the determinant factors from the intrinsic domain to strengthen the intention. Further, the intention which comes from intrinsic factors will be converted to more sustainable behaviour (Kattoua 


\section{For More Pages, Please Go To https://dx.doi.org/10.22034/gjesm.2021.02.10}




\section{For More Pages, Please Go To https://dx.doi.org/10.22034/gjesm.2021.02.10}


For More Pages, Please Go To
https://dx.doi.org/10.22034/gjesm.2021.02.10 
to boost intrinsic factors on an emotional level by improving residents' knowledge of key contents. The knowledge acquisition influences the intrinsic factors improvement on emotional level, leading the expected behaviour. The changing behaviour becomes the indication that the residents willingly participate in waste management. Improving waste management participation by nurturing key intrinsic factors, supported by external factors and habituation, is essential to keep the participation long-lasting. With full support from the antecedent factors, waste management behaviour can be sustainable, which eventually increases the participation rate significantly. However, the impact degree of antecedent factors, extrinsic and intrinsic, can be contextually different from one city to another. Therefore, educational contents' relevance to the residents' environmental problems is highly encouraged to nurture the critical intrinsic factors. The familiarity of educational materials to the residents' waste problems will make the knowledge more impactful. The educational contents are delivered through resident-based education using various techniques and approaches implemented by adjusting the residents' characteristics. The primary requirements for education are durable learning, allow intensive interaction, and enable learningby-doing to establish new habits and improve performance. The fundamental goal of the education is to enable the transformation of intrinsic factors on the knowledge level to intrinsic factors on the emotional level. Without the existence of intrinsic factors in the emotional domain, the expected behaviour would not be sustainable. If the emotional domain can reach the maximum level, the behaviour can be sustainable even without being moderated by extrinsic factors. However, achieving such a top level of the emotional domain might be hard to reach. Thus, it is recommended to combine extrinsic and intrinsic factors to ensure sustainable resident participation effectiveness. The relationship between key extrinsic and intrinsic factors is presented in Fig. 3.

\section{AUTHOR CONTRIBUTIONS}

Sunarti was responsible for searching the bibliography, selecting the relevant references, coding the references, writing the initial manuscript draft, synthesising the manuscript, revising the final manuscript version. J.H. Tjakraatmadja was

responsible for conceptualizing the draft, analysing the references' coding, and reviewing the whole manuscript. A. Ghazali was responsible for the work plan preparation, defining the bibliographic search, conceptualizing the draft, review the whole manuscript. B. Rahardyan was responsible for the selecting the relevant references, analysing the coding of the references, and reviewing the analysis in the manuscript.

\section{ACKNOWLEDGEMENT}

Authors are thankful for the financial support provided by Indonesia Endowment Fund for Education (LPDP) with the contract number [201708210811406]. The authors also acknowledge the anonymous reviewers for their valuable comments and suggestions given through the $2^{\text {nd }}$ International Graduate Colloquium (IGC) conducted by the School of Business Management (SBM) ITB on $3^{\text {th }}-4^{\text {th }}$ August 2020 in Bandung City, Indonesia, that helped improve this manuscript. In addition, valuable inputs from the bi-weekly Progress Report session conducted by the People and Knowledge Management (PKM) Expertise Group in School of Business Management (SBM) ITB are also appreciated to improve the manuscript.

\section{CONFLICT OF INTEREST}

The authors declare no potential conflict of interest regarding the publication of this work. In addition, the ethical issues including plagiarism, informed consent, misconduct, data fabrication and, or falsification, double publication and, or submission, and redundancy have been completely witnessed by the authors.

\section{ABBREVIATIONS}

$\%$

$3 R$

$A A A$

e.g.

Fig.

GHG

IGC

MSW

NVIVO R1

$\angle P D P$
Per cent

Reuse, reduce, recycle

Ayla aviation academy

Exempli gratia/for example

Figure

Greenhouse gas International graduate colloquium Municipal solid waste A qualitative data analysis software provided by QSR International

Lembaga pengelola dana pendidikan 


$\begin{array}{ll}\text { PAYT } & \text { Pay as you throw } \\ \text { PBC } & \text { Perceived behavioural control } \\ \text { PET } & \text { Polyethylene terephthalate } \\ \text { PKM } & \text { People and knowledge management } \\ \text { SBM } & \text { School of business management } \\ \text { UAE } & \text { United Arab Emirates } \\ \text { USD } & \text { United States dollar } \\ W M & \text { Waste management }\end{array}$

\section{REFERENCES}

Abbasi, S.A., (2018). The myth and the reality of energy recovery from municipal solid waste. Energy Sustainability Soc., 8(36): 1-15 (15 pages).

Abdelradi, F., (2018). Food waste behaviour at the household level: A conceptual framework. Waste Manage., 71: 485-493 (9 pages).

Abdulredha, M.; Kot, P.; Al-Khaddar, R.; Jordan, D.; Abdulridha, A., (2020). Investigating municipal solid waste management system performance during the Arba'een event in the city of Kerbala, Iraq. Environ. Dev. Sustainability, 22: 1431-1454 (24 pages).

Addo, H.O.; Dun-dery, E.J.; Afoakwa, E.; Elizabeth, A.; Ellen, A.; Rebecca, M., (2017). Correlates of domestic waste management and related health outcomes in Sunyani, Ghana: a protocol towards enhancing policy. BMC Public Health, 17(615): 1-10 (10 pages).

Ajzen, I., (2005). Attitudes, personality and behavior (2nd ed.). McGraw-Hill, United Kingdom (192 pages).

Akhtar, S.; Ahmad, A.S.; Qureshi, M.I.; Shahraz, S., (2017). Households willingness to pay for improved solid waste management. Global J. Environ. Sci. Manage., 3(2): 143-152 (10 pages).

Al-Khateeb, A.J.; Al-Sari, M.I.; Al-Khatib, I.A.; Anayah, F., (2017). Factors affecting the sustainability of solid waste management system - the case of Palestine. Environ. Monit. Assess., 189(93): 1-12 (12 pages).

Al-Naggar, R.A.; Abdulghani, M.A.M.; Al-Areefi, M.A., (2019). Effects of inappropriate waste management on health: knowledge, attitude and practice among Malaysian population. Malaysian J. Public Health Med., 19(1): 101-109 (9 pages).

Aleluia, J.; Ferrão, P., (2016). Characterization of urban waste management practices in developing Asian countries: A new analytical framework based on waste characteristics and urban dimension. Waste Manage., 58: 415-429 (15 pages).

Alhassan, H.; Kwakwa, P.A.; Owusu-Sekyere, E., (2020). Households' source separation behaviour and solid waste disposal options in Ghana's Millennium City. J. Environ. Manage., 259(110055): 1-10 (10 pages).

Al-Khatib, I.A.; Arafat, H.A.; Daoud, R.; Shwahneh, H., (2009). Enhanced solid waste management by understanding the effects of gender, income, marital status, and religious convictions on attitudes and practices related to street littering in Nablus Palestinian territory. Waste Manage., 29: 449-455 (7 pages).

Almasi, A.; Mohammadi, M.; Azizi, A.; Berizi, Z.; Shamsi, K.;
Shahbazi, A.; Mosavi, S.A., (2019). Assessing the knowledge, attitude and practice of the Kermanshahi women towards reducing, recycling and reusing of municipal solid waste. Resour. Conserv. Recycl., 141: 329-338 (10 pages).

Areeprasert, C.; Kaharn, J.; Inseemeesak, B.; Phasee, P.; Khaobang, C.; Kuhavichanun, A.; Theerarojprateep, P.,; Siwakosit, W., (2018). A comparative study on characteristic of locally sourceseparated and mixed MSW in Bangkok with possibility of material recycling. J Mater Cycles Waste Manag., 20:302-313 (12 pages).

Ayodele T.R.; Alao M.A.; Ogunjuyigbe A.S.O., (2018). Recyclable resources from municipal solid waste: Assessment of its energy, economic and environmental benefits in Nigeria. Resour. Conserv. Recycl., 134: 165-173 (9 pages).

Astane, A.R.D.; Hajilo, M., (2017). Factors affecting the rural domestic waste generation. Global Environ. Sci. Manage., 3(4): 417-426 (10 pages).

Ayob, S.F.; Sheau-Ting, L.; Abdul Jalil, R.; Chin, H.C., (2017). Key determinants of waste separation intention: empirical application of TPB. Facil., 35(11/12): 696-708 (13 pages).

Banerjee, S.; Sarkhel, P., (2019). Municipal solid waste management, household and local government participation: a cross country analysis. J. Environ. Plann. Manage., 63(2): 210235 (27 pages).

Benešová, L.; Doležalová, M.; Hnatuková, P.; Černík, B., (2010). Municipal solid waste: character and composition. In A. K. HAGHI (Ed.), Waste Manag. Res. Adv. To Convert Waste To Wealth. Nova Science Publishers, New York. 33-80 (48 pages).

Boonrod, K.; Ayudhaya, P.T. na; YuenYong, Y., (2019). Enhancing organic waste management behavior: A case of Thailand. Proc. ICSAI Conf., 13: 20-31 (12 pages).

Borongan, G.; Okumura, S., (2010). Municipal waste management report: status-quo and sssues in Southeast and East Asian Countries. AIT/UNEP, UNT Digital Library (43 pages).

Choon, S.W.; Tan, S.H.; Chong, L.L., (2017). The perception of households about solid waste management issues in Malaysia. Environ. Dev. Sustainability, 19: 1685-1700 (16 pages).

Chow, C.F.; So, W.M.W.; Cheung, T.Y.; Yeung, S.K.D., (2017). Plastic waste problem and education for plastic waste management. In S.C. Kong, T.L. Wong, M. Yang, C.F. Chow, \& K.H. Tse (Eds.), Emerging practices in scholarship of learning and teaching in a digital era (pp. 125-140). Springer Nature, Singapore (16 pages).

Elayan, M.; Ibrawish, E., (2017). Factors influencing the implementation of recycling: Evidence from ayla aviation academy in Jordan. Int. J. Econ. Perspect., 11(1): 354-377 (24 pages).

Elkiran, E.; Nourani, V.; Abba, S.I.; Abdullahi, J., (2018). Artificial intelligence-based approaches for multi-station modelling of dissolve oxygen in river. Global J. Environ. Sci. Manage., 4(4): 439-450 (12 pages).

Eneji, C.-V.O.; Onnoghen, U.N.; Edung, A.E.; Effiong, G.O., (2019). Environmental education and waste management behavior among undergraduate students of the university of Calabar, Nigeria. J. Educ. Pract., 10(24): 76-85 (10 pages).

Esmaeilizadeh, S.; Shaghaghi, A.; Taghipour, H., (2020). Key informants' perspectives on the challenges of municipal solid 
waste management in Iran: a mixed method study. J. Mater. Cycles Waste Manage., 22(4): 1284-1298 (15 pages).

Fan, B.; Yang, W.; Shen, X., (2019). A comparison study of 'motivation-intention-behavior' model on household solid waste sorting in China and Singapore. J. Cleaner Prod., 211: 1-33 (33 pages).

Fink, A., (2014). Conducting research literature reviews: from the internet to paper (4th ed.). Sage Publications, Singapore (245 pages).

Fredrick, M.; Oonyu, J.C.; Sentongo, J., (2018). Influence of education on the solid waste management practices of communities in Kampala City. J. Environ. Waste Manage., 5(1): 261-274 (14 pages).

Gyimah, P.; Mariwah, S.; Antwi, K.B.; Ansah-Mensah, K., (2019). Households' solid waste separation practices in the Cape Coast Metropolitan area, Ghana. GeoJournal, 4: 1-17 (17 pages).

Hammami, M.B.A.; Mohammed, E.Q.; Hashem, A.M.; Al-Khafaji, M.A.; Alqahtani, F.; Alzaabi, S.; Dash, N., (2017). Survey on awareness and attitudes of secondary school students regarding plastic pollution: implications for environmental education and public health in Sharjah city, UAE. Env. Sci Pollut Res, 24: 20626 20633 (8 pages).

Hartmann, C., (2018). Waste picker livelihoods and inclusive neoliberal municipal solid waste management policies: The case of the La Chureca garbage dump site in Managua, Nicaragua. Waste Manage., 71: 565-577 (13 pages).

Heidari, A.; Kolahi, M.; Behravesh, N.; Ghorbanyon, M.; Ehsanmansh, F.; Hashemolhosini, N.; Zanganeh, F., (2018). Youth and sustainable waste management: a SEM approach and extended theory of planned behavior. J. Mater. Cycles Waste Manage., 20: 2041-2053 (13 pages).

Hollingworth, C.; Barker, L., (2017). How to use behavioural science to build new habits. WARC, : 1-18 (18 pages).

Idamah, A.P., (2015). Influence of broadcast media enlightenment campaigns on solid waste management in South-South of Nigeria. New Media Mass Commun., 39: 10-62 (53 pages).

Issock, P.B.I.; Roberts-Lombard, M.; Mpinganjira, M., (2020). Normative influence on household waste separation: the moderating effect of policy implementation and sociodemographic variables. Soc. Mar. Q., 26(2): 93-110 (18 pages).

Janmaimool, P.; Denpaiboon, C., (2016). Evaluating determinants of rural Villagers' engagement in conservation and waste management behaviors based on integrated conceptual framework of Pro-environmental behavior. Life Sci. Soc. Policy, 12(12): 1-20 (20 pages).

Kamaruddin, M.A.; Yusoff, M.S.; Rui, L.M.; Isa, A.M.; Zawawi, M.H.; Alrozi, R., (2017). An overview of municipal solid waste management and landfill leachate treatment: Malaysia and Asian perspectives. Environ. Sci. Pollut. Res., 24: 26988-27020 (33 pages).

Kattoua, M.G.; Al, I.A.; Stamatia, K., (2019). Barriers on the propagation of household solid waste recycling practices in developing countries: State of Palestine example. J. Mater. Cycles Waste Manage., 21: 774-785 (12 pages).

Kawai, K.; Huong, L.T.M.; Yamada, M.; Osako, M., (2016). Proximate composition of household waste and applicability of waste management technologies by source separation in Hanoi, Vietnam. J. Mater. Cycles Waste Manage., 18: 517-526 (10 pages).

Knickmeyer, D., (2019). Social factors influencing household waste separation: A literature review on good practices to improve the recycling performance of urban areas. J. Cleaner Prod., 245(118605): 1-41 (41 pages).

Kokkinos, K.; Karayannis, V.; Lakioti, E.; Moustakas, K., (2019). Exploring social determinants of municipal solid waste management: survey processing with fuzzy logic and selforganized maps. Environ. Sci. Pollut. Res., 26(35): 35288-35304 (17 pages).

Laohalidanond, K.; Chaiyawong, P.; Kerdsuwan, S., (2015). Municipal Solid Waste Characteristics and Green and Clean Energy Recovery in Asian Megacities. Energy Procedia, 79: 391 - 396 (6 pages).

Lawrence, K.; Cooper, V.; Kissoon, P., (2020). Sustaining voluntary recycling programmes in a country transitioning to an integrated solid waste management system. J. Environ. Manage., 257(109966): 1-7 (7 pages).

Lee, C.K.M.; Ng, K.K.H.; Kwong, C.K.; Tay, S.T., (2018). A system dynamics model for evaluating food waste management in Hong Kong, China. J. Mater. Cycles Waste Manage., 21: 433-456 (24 pages).

Li, C.J.; Huang, Y.Y.; Harder, M.K., (2017). Incentives for food waste diversion: Exploration of a long term successful Chinese city residential scheme. J. Cleaner Prod., 156: 491-499 (9 pages).

Liao, C.; Zhao, D.; Zhang, S.; Chen, L., (2018). determinants and the moderating effect of perceived policy effectiveness on residents' separation intention for rural household solid waste. Int. J. Environ. Res. Public Health, 15(726): 1-18 (18 pages).

Lickona, T., (1991). Educating for character: how our schools can teach respect and responsibility. Bantam Books, New York (478 pages).

Lim, S.L.; Lee, L.H.; Wu, T.Y., (2016). Sustainability of using composting and vermicomposting technologies for organic solid waste biotransformation: recent overview, greenhouse gases emissions and economic analysis. J. Cleaner Prod., 111: 262-278 (17 pages).

Limon, M.R.; Vallente, J.P.C.; Corales, N.C.T., (2020). Solid waste management beliefs and practices in rural households towards sustainable development and pro-environmental citizenship. Global J. Environ. Sci. Manage., 6(4): 441-456 (16 pages).

Liu, X.; Wang, Z.; Li, W.; Li, G.; Zhang, Y., (2019). Mechanisms of public education influencing waste classification willingness of urban residents. Resour. Conserv. Recycl., 149: 381-390 (10 pages).

Loan, L.T.T.; Nomura, H.; Takahashi, Y.; Yabe, M., (2017). Psychological driving forces behind households' behaviors toward municipal organic waste separation at source in Vietnam: a structural equation modeling approach. J Mater Cycles Waste Manag., 19: 1052-1060 (9 pages).

Ma, J.; Hipel, K.W.; Hanson, M.L., (2018). An evaluation of the social dimensions in public participation in rural domestic waste source-separated collection in Guilin, China. Environ. Monit. Assess., 190(35): 1-14 (14 pages).

Ma, Y.; Koondhar, M.A.; Liu, S.; Wang, H.; Kong, R., (2020). 
Perceived value influencing the household waste sorting behaviors in rural China. Int. J. Environ. Res. Public Health, 17(17): 1-18 (19 pages).

Mamady, K., (2016). Factors influencing attitude, safety behavior, and knowledge regarding household waste management in Guinea: A Cross-Sectional Study. J. Environ. Public Health, 2016(9305768): 1-9 (9 pages).

Marshall, R.E.; Farahbakhsh, K., (2013). Systems approaches to integrated solid waste management in developing countries. Waste Manage., 33: 988-1003 (16 pages).

Maryati, S.; Arifiani, N.F.; Humaira, A.N.S.; Putri, H.T., (2018). Factors influencing household participation in solid waste management (Case study: Waste Bank Malang). IOP Conf. Ser.: Earth Environ. Sci., 124: 1-5 (5 pages).

Meng, X.; Wen, Z.; Qian, Y., (2018). Multi-agent based simulation for household solid waste recycling behavior. Resour. Conserv. Recycl., 128: 535-545 (11 pages).

Meng, X.; Tan, X.; Wang, Y.; Wen, Z.; Tao, Y.; Qian, Y., (2019). Investigation on decision-making mechanism of residents' household solid waste classification and recycling behaviors. Resour. Conserv. Recycl., 140: 224-234 (11 pages).

Minelgaitè, A.; Liobikienè, G., (2019). Waste problem in European Union and its influence on waste management behaviours. Sci. Total Environ., 667: 86-93 (8 pages).

Mintz, K.K.; Henn, L.; Park, J.; Kurman, J., (2019). What predicts household waste management behaviors? Culture and type of behavior as moderators. Resour. Conserv. Recycl., 145: 11-18 (8 pages).

Modak, P.; Wilson, D.C.; Velis, C., (2016). Waste management: global status. In T. Cannon (Ed.), Global Waste Management Outlook (pp. 51-124). International Solid Waste Association, Austria (74 pages).

Mohamad, Z.F.; Idris, N.; Baharuddin, A.; Muhammad, A.; Sulaiman, N.M.N., (2012). The role of religious community in recycling: Empirical insights from Malaysia. Resour. Conserv. Recycl., 58: 143-151 (9 pages).

Mukama, T.; Ndejjo, R.; Musoke, D.; Musinguzi, G.; Halage, A.A.; Carpenter, D.O.; Ssempebwa, J.C., (2016). Practices, concerns, and willingness to participate in solid waste management in two urban slums in Central Uganda. J. Environ. Public Health, 2016(6830163): 1-7 (7 pages).

Musella, G.; Agovino, M.; Casaccia, M.; Crociata, A., (2018). Evaluating waste collection management: the case of macroareas and municipalities in Italy. Environ. Dev. Sustainability, 21: 2857-2889 (33 pages).

Navykarn, K.; Muneenam, U., (2015). Waste management education for sustainable islands. Appl. Mech. Mater., 804: 271-274 (4 pages).

Ng, T.S.; Wang, S., (2017). Recycling systems design using reservation incentive data. J. Oper. Res. Soc., 68(10): 1236-1258 (23 pages).

Nguyen, T.T.; Watanabe, T., (2019). Win-win outcomes in waste separation behavior in the rural area: A case study in vietnam. J. Cleaner Prod., 230: 488-498 (11 pages).

Nmere, O.N.; Okolo, V.O.; Abugu, J.O.; Alio, F.C.; Aneto, J.C., (2020). Influence of public relations' media public enlightenment campaign and community participation strategies on waste management. Prob. Perspect. Manage., 18(1): 82-96 (15 pages).

Nnaji, C.C., (2015). Status of municipal solid waste generation and disposal in Nigeria. Manage. Environ. Qual. An Int. J., 26(1): 53-71 (19 pages).

Oduro-Kwarteng, S.; Anarfi, K.P.; Essandoh, H.M.K., (2016). Source separation and recycling potential of municipal solid waste in Ghana. Manage. Environ. Qual. An Int. J., 27(2): 210-226 (17 pages).

Owamah, I.H.; Izinyon, O.C.; Igbinewekan, P., (2017). Characterization and quantification of solid waste generation in the Niger Delta Region of Nigeria: a case study of Ogbe-ljoh community in Delta State. J. Mater. Cycles Waste Manage., 19: 366-373 (9 pages).

Padilla, A.J.; Trujillo, J.C., (2018). Waste disposal and households? heterogeneity. Identifying factors shaping attitudes towards source-separated recycling in Bogotá, Colombia. Waste Manage., 74: 16?33 (18 pages).

Pandyaswargo, A.H.; Premakumara, D.G.J., (2014). Financial sustainability of modern composting: the economically optimal scale for municipal waste composting plant in developing Asia. Int. J. Recycl. Org. Waste Agricult., 3: 1-14 (14 pages).

Pasaribu, Y.A.; Buchari, A.; Wani Eka Putri Perangin-angin, R.; Saragih, J., (2020). Factors that influence people behaviors in waste management in the village of Tong Marimbun Pematang Siantar in 2018. Int. J. Sci. Healthcare Res., 5(1): 143-149 (7 pages).

Priti; Mandal, K., (2019). Review on evolution of municipal solid waste management in India: practices, challenges and policy implications. J. Mater. Cycles Waste Manage., 21: 1263-1279 (17 pages).

Putri, A.R.; Fujimori, T.; Takaoka, M., (2018). Plastic waste management in Jakarta, Indonesia: evaluation of material flow and recycling scheme. J. Mater. Cycles Waste Manage., 20: 2140-2149 (10 pages).

Ramadan, B.S.; ALam, F.C.; Rahardyan, B., (2016). The influence of environmental campaign on public awareness in maintaining the cleanliness and waste reduction program: a case study of Bandung City. Sci. J. PPI-UKM, 3(1): 32-37 (6 pages).

Salem, M.; Raab, K.; Wagner, R., (2020). Solid waste management: The disposal behavior of poor people living in Gaza Strip refugee camps. Resour. Conserv. Recycl., 153(104550): 1-9 (9 pages).

Sari, M.D.P.; Umanto., (2014). The design of change in waste management policy: application of soft systems methodology. Bisnis \& Birokrasi, 20(3): 153-162 (10 pages).

Sekito, T.; Prayogo, T.B.; Meidiana, C.; Shimamoto, H.; Dote, Y., (2018). Estimating the flow of recyclable items and potential revenue at a waste bank: the case in Malang City, Indonesia. Environ. Dev. Sustainability, 21(6): 2979-2995 (17 pages).

Setiawan, R.P., (2020). Factors determining the public receptivity regarding waste sorting: A case study in Surabaya city, Indonesia. Sustainable Environ. Res., 30(1): 1-8 (8 pages).

Setiawan, R.P.; Kaneko, S.; Kawata, K., (2019). Impacts of pecuniary and non-pecuniary information on pro-environmental behavior: A household waste collection and disposal program in Surabaya city. Waste Manage., 89: 322-335 (14 pages).

Singer, J.; Kieu, K.T.; Pravitasari, A.E., (2019). Solid waste 
management in tourist destinations in developing nations: case studies in Hoi An, Vietnam, and Puncak, Indonesia. In W. W. M. So, C. F. Chow, \& J. C. K. Lee (Eds.), Environ. Sustain. Educ. Waste Manage. (pp. 189-206). Springer Nature, Singapore (18 pages).

So, W.W.M.; Lee, J.C.K.; Chow, C.F., (2019). Environmental sustainability and education for waste management. In W.W.M. So, C.F. Chow, \& J.C.K. Lee (Eds.), environmental sustainability and education for waste management. Education for Sustainability (pp. 1-11). Springer, Singapore (11 pages).

Song, Q.; Wang, Z.; Li, J., (2016). Exploring residents' attitudes and willingness to pay for solid waste management in Macau. Environ. Sci. Pollut. Res., 23: 16456-16462 (8 pages).

Speier, C.J.; Mondal, M.M; Weichgrebe, D., (2018). Evaluation of compositional characteristics of organic waste shares in municipal solid waste in fast-growing metropolitan cities of India. J. Mater. Cycles Waste Manag., 20: 2150-2162 (13 pages).

Stern, P.C., (1999). Information, incentives, and proenvironmental consumer behavior. J. Consum. Policy, 22: 461-478 (18 pages).

Stern, P.C.; Dietz, T.; Abel, T.D.; Guagnano, G.; Kalof, L., (1999). A value-belief-norm theory of support for social movements: the case of environmentalism. Res. Hum. Ecol., 6(2): 81-97 (18 pages).

Sujata, M.; Khor, K.S.; Ramayah, T.; Teoh, A.P., (2019). The role of social media on recycling behaviour. Sustainable Prod. Consumption, 20: 365-374 (10 pages).

Sukholthaman, P.; Chanvarasuth, P.; Sharp, A., (2017). Analysis of waste generation variables and people's attitudes towards waste management system: a case of Bangkok, Thailand. J. Mater. Cycles Waste Manage., 19(2): 645-656 (12 pages).

Tiew, K.G.; Basri, N.E.A.; Zain, S.M.; Watanabe, K.; Mohamad, W.N.A.W., (2015a). Assessment of Factors Attracting Waste Recycler Behaviors By Rasch Model. Jurnal teknologi, 72: 63-70 (8 pages).

Tiew, K.G.; Basri, N.E.A.; Watanabe, K.; Abushammala, M.F.M.; Bin Ibrahim, M.T., (2015b). Assessment of the sustainability level of community waste recycling program in Malaysia. J. Mater. Cycles Waste Manage., 17: 598-605 (8 pages).

Trihadiningrum, Y.; Laksono, I.J.; Dhokhikah, Y.; Moesriati, A.; Radita, D.R.; Sunaryo, S., (2017). Community activities in residential solid waste reduction in Tenggilis Mejoyo District, Surabaya City, Indonesia. J. Mater. Cycles Waste Manage., 19: 526-535 (10 pages).

Turaga, R.M.R.; Howarth, R.B.; Borsuk, M.E., (2010). Proenvironmental behavior: rational choice meets moral motivation. Ann. N.Y. Acad. Sci., 1185: 211-224 (14 pages).

Ulhasanah, N.; Goto, N., (2018). Assessment of citizens' environmental behavior toward municipal solid waste management for a better and appropriate system in Indonesia: a case study of Padang City. J. Mater. Cycles Waste Manage., 20: 1257-1272 (16 pages).

Wadehra, S.; Mishra, A., (2018). Encouraging urban households to segregate the waste they generate: Insights from a field experiment in Delhi, India. Resour. Conserv. Recycl., 134: 239247 (9 pages).

Wang, H.; Liu, X.; Wang, N.; Zhang, K.; Wang, F.; Zhang, S.; Wang, R.; et al., (2020a). Key factors influencing public awareness of household solid waste recycling in urban areas of China: A case study. Resour. Conserv. Recycl., 158(104813): 1-9 (9 pages).

Wang, S.; Wang, J.; Yang, S.; Li, J.; Zhou, K., (2020b). From intention to behavior: Comprehending residents' waste sorting intention and behavior formation process. Waste Manage., 113: 41-50 (10 pages).

Wang, Y.; Hao, F., (2020). Public perception matters: Individual waste sorting in Chinese communities. Resour. Conserv. Recycl., 159(104860): 1-12 (12 pages).

Wichai-utcha, N.; Chavalparit, O., (2019). 3Rs Policy and plastic waste management in Thailand. J. Mater. Cycles Waste Manage., 21(1): 10-22 (13 pages).

World Bank., (2018). Solid waste management. The World Bank Group (1 pages).

Xiao, L.; Zhang, G.; Zhu, Y.; Lin, T., (2017). Promoting public participation in household waste management: A survey based method and case study in Xiamen city, China. J. Cleaner Prod., 144: 313-322 (10 pages).

Xu, L.; Lin, T.; Xu, Y.; Xiao, L.; Ye, Z.; Cui, S., (2016). Path analysis of factors influencing household solid waste generation: a case study of Xiamen Island, China. J. Mater. Cycles Waste Manag., 18:377-384 (8 pages).

Xu, L.; Ling, M.; Lu, Y.; Shen, M., (2017). Understanding household waste separation behaviour: testing the roles of moral, past experience, and perceived policy effectiveness within the theory of planned behaviour. Sustainability, 9(625): 1-27 (27 pages).

$\mathrm{Xu}$, L.; Ling, M.; Wu, Y., (2018). Economic incentive and social influence to overcome household waste separation dilemma: a field intervention study. Waste Manage., 77: 522-531 (10 pages).

Yeh, L.T.; Chang, D.S.; Liu, W., (2016). The effect of organizational learning on the dynamic recycling performance of Taiwan's municipal solid waste (MSW) system. Clean. Techn. Environ. Policy, 18: 1535-1550 (16 pages).

Yeung, I.M.H.; Chung, W., (2018). Factors that affect the willingness of residents to pay for solid waste management in Hong Kong. Environ. Sci. Pollut. Res., 25: 7504-7517 (14 pages).

Yuan, Y.; Nomura, H.; Takahashi, Y.; Yabe, M., (2016). Model of chinese household kitchen waste separation behavior: a case study in Beijing City. Sustainability, 8(1083): 1-15 (15 pages).

Yukalang, N.; Clarke, B.; Ross, K., (2017). Barriers to effective municipal solid waste management in a rapidly urbanizing area in Thailand. Int. J. Environ. Res. Public Health, 14(1013): 1-23 (23 pages).

Zacho, K.O.; Mosgaard, M.A., (2016). Understanding the role of waste prevention in local waste management: A literature review. Waste Manage. Res., 34(10): 980-994 (15 pages).

Zahra, K.; Majeed, K.; Mahmood, A.; Asad, M., (2012). Impact assessment of community participation in solid waste management projects in selected areas of Faisalabad City. J. Urban Plann. Dev., 138(4): 319-328 (10 pages).

Zhang, B.; Lai, K. hung; Wang, B.; Wang, Z., (2019). From intention to action: How do personal attitudes, facilities accessibility, and government stimulus matter for household waste sorting? J. Environ. Manage., 233: 447-458 (12 pages). 


\section{AUTHOR (S) BIOSKETCHES}

Sunarti, Ph.D. Candidate, School of Business and Management, Institut Teknologi Bandung, Indonesia. Email: sunarti@sbm-itb.ac.id

Tjakraatmadja, J.H., Ph.D., Professor, School of Business and Management, Institut Teknologi Bandung, Indonesia.

Email: jannhidajat@sbm-itb.ac.id

Ghazali, A., Ph.D., Assistant Professor, School of Business and Management, Institut Teknologi Bandung, Indonesia.

Email: achmadghazali@sbm-itb.ac.id

Rahardyan, B., Ph.D., Associate Professor, Faculty of Civil and Environmental Engineering, Institut Teknologi Bandung, Indonesia.

Email: benno@ftsl.itb.ac.id

\section{COPYRIGHTS}

C2021 The author(s). This is an open access article distributed under the terms of the Creative Commons Attribution (CC BY 4.0), which permits unrestricted use, distribution, and reproduction in any medium, as long as the original authors and source are cited. No permission is required from the authors or the publishers.

\section{HOW TO CITE THIS ARTICLE}

Sunarti; Tjakraatmadja, J.H.; Ghazali, A.; Rahardyan, B., (2021). Increasing resident participation in waste management through intrinsic factors cultivation. Global J. Environ. Sci. Manage., 7(2): 287-316.

DOI: $10.22034 /$ gjesm.2021.02.10

url: https://www.gjesm.net/article_47890.html 